\title{
Review
}

\section{How we became our data: A genealogy of the informational person}

\author{
Colin Koopman, \\ University of Chicago Press, Chicago and London, 2019, x+269pp., ISBN: \\ 978-0226626444
}

Contemporary Political Theory (2021) 20, S160-S163. https://doi.org/10.1057/s41296020-00432-2; published online 24 July 2020

In the wake of Michel Foucault's analyses of disciplinary surveillance and biopolitical regulations, or of Gilles Deleuze's remarks on the 'society of control', in the past few years, many political theorists have developed compelling work on so-called 'data politics'. From Maurizio Lazzarato's 'noopolitics' and Tiziana Terranova's 'communication biopower' to Grégoire Chamayou's 'datapower' and Davide Panagia's '\#datapolitik' (to mention only a few examples; for a more detailed list, see p. 169), it is widely accepted that one of the main ways in which power now functions is by collecting, storing, and exchanging vast amounts of personal data. Colin Koopman's book, How We Became Our Data, does not merely add to this already vast literature new insights on what he calls 'infopolitics' (i.e. the politics of information) and 'informational persons' (claiming that we are invariably 'inscribed, processed, and reproduced as subjects of data', p. 4). Drawing from Foucault - both methodologically and conceptually - Koopman advances two original claims that have the ambition to transform some of the most deeply rooted assumptions in the field of data politics.

First, Koopman convincingly argues that to understand how information became so important for the kind of subjects we are today, we should avoid focusing exclusively on the last few decades - that is, on the age of personal computing, internet, and social media. We should also problematise the widely accepted narrative that our 'information era' began in the aftermath of WWII, and more precisely with the elaboration, in 1948, of the so-called Wiener-Shannon theory of information (pp. 16-17). At the same time, Koopman argues that informational persons are not to be confused with confessing individuals and statisticalised populations of the nineteenth century. Informational personhood emerged between the mid-1910s and the mid-1930s. Indeed, the way in which subjects started to be formatted into data at that time (through birth certificates, psychological assessments, education records, financial profiles, etc.) still remains with us today. Koopman provides convincing historical evidence for this claim by analysing in

(C) 2020 Springer Nature Limited. 1470-8914 Contemporary Political Theory Vol. 20, S4, S160-S163 www.palgrave.com/journals 
great detail three different vectors of the informationalisation of selfhood: birth certificates and 'documentary identity' (chapter 1), personality metrics and 'psychological identity' (chapter 2), real estate appraisal and 'racial identity' (chapter 3). These three vectors - the informatics of 'human bookkeeping', the informatics of personality traits, and the informatics of racialised credit - certainly do not exhaust all the traits that characterise our informational self, but it is clear that they are still 'crucial for who we can be in the present' (p. 20).

It is important to emphasise that Koopman is not only interested in historical accuracy. An essay in Foucauldian genealogy, his book successfully resists the temptation to frame its historical arguments in terms of the discovery of an Ursprung, that is, the singular origin of a given phenomenon (here, the datafication of the subject) construed as its essential foundation or universal nature (Foucault, 1984a). Instead, it explores a multiplicity of events which all contributed to the complex formation of the informational persons that we still are. Thus, Koopman's genealogy plays with our sense of what it is possible for us to do and to be. On the one hand, it shows us that we are less free than we think, since 'our data do not simply point at who we already were before information systems were constructed', but they are 'active participants in our making'; they literally 'shape who we are', to the point that 'we inhabit lives that rely on data in nearly every act we perform' (pp. vii, ix). On the other hand, however, by disrupting the false impression that information has no history and showing how it came to be universalised, genealogy problematises our 'tendency to take information technologies as closed, locked, and unchangeable', and helps us realise that the history of information is made by 'a set of moments when data was not yet closed, but rather glaringly open to contestation and recomposition' (p. ix). Hence, by exposing 'the contingency that has made us what we are', Koopman's genealogy of the informational person also aims to open up 'the possibility of no longer being, doing, or thinking what we are, do, or think' (Foucault, 1984b, p. 46). This 'possibility' is not just abstract, but takes the form of the elaboration and practice of multiple resistances in the present - especially what Koopman calls 'resistant informatics' (p. 193). Genealogy is thus 'a practice of critique' (p. 23): not because it tells us what is right or wrong, but because it reveals the (historical) conditions of possibility that make us who we are and define the limits of what we can do, while also unveiling their contingency in order to destabilise them and open up the space for change.

Second, Koopman persuasively argues that the specific mode of power which correlates with his genealogy of the informational person cannot be reduced to the main forms of power theorised by Foucault - namely, sovereignty, discipline, and biopolitics. In chapter 4 , he shows that infopower is not a data-driven biopower or a disciplinary informatics but a distinctive modality of power that 'conducts' individuals through an uninterrupted process of 'formatting'. More precisely, information's formats fasten us to our data in a double sense: they tie us down and speed us up, they canalise and accelerate the (informational) persons that they

(c) 2020 Springer Nature Limited. 1470-8914 Contemporary Political Theory Vol. 20, S4, S160-S163 S161 
produce (pp. 156-157). Consequently, as Koopman goes on to argue in chapter 5, the main models of resistance that critical theorists have elaborated so far are ineffective to confront infopower. In particular, John Dewey's and Jürgen Habermas's theories of communicative democracy are unable to construe information itself as a political issue because, far from problematising it, they take it for granted: 'any project of communication must be dependent on prior projects of the formation of information' (p. 181); therefore, 'any attempt to confront information as a pure function of communication is bound to leave intact those formats that any communicative process must presuppose' (p. 185). Deepening and complicating Foucault's critique of Habermas's idealising presuppositions of communicative action, Koopman emphasises that these theories are unable to address 'information perfectly capable of being freely communicated and yet nevertheless politically problematic or dangerous in other ways', since 'it is only when formats distort communication that communicative proceduralism can countenance them'. Thus, they are bound to ignore the 'independent politics of formats not parasitic upon whatever communicative interaction happens to transmit those formats' (p. 187). What Koopman's book ultimately shows, then, is that we need a (new) normative political theory that is able to address 'the processes of informationalisation that precede, and are invoked by, all communicative processes' (p. 189). Much as there is no 'essential self' from which our data alienate us, because our present self is in no small part produced and defined precisely by those data (p. 8), there is no 'ideal' deliberative democracy which (info)power prevents us from realising, because current democratic communication crucially relies on infopower for the production, formatting, and exchange of information.

There are two final points that I would like to mention here. On the one hand, Koopman's book is entirely successful in showing that 'we are our data', or better, that 'data has become a crucial part of the very terms by which we can conduct ourselves' (p. 170). There is, however, an aspect of this historical process of datafication of our self that Koopman does not explore in great detail, but that seems to be particularly important: the element of desire. Indeed, we are not only informational persons but also desiring subjects - that is, we are not only 'governed' through data and formats but also through the production and reproduction of desires (Harcourt, 2015; Beistegui, 2018). In many ways, these two modalities of governing individuals appear to be correlative and to reinforce each other in neoliberal societies: information's formats, by fastening us to our data, also fasten us to our desires. Thus, the genealogy of the informational person and the genealogy of the subject of desire could be fruitfully combined in order to problematise this dangerous alliance. On the other hand, one of the most interesting - and (unfortunately) timely - passages of the book is Koopman's elaboration of the notion of 'technological racism', which aims to draw attention to 'the technical mechanisms of how purportedly neutral information systems can unexpectedly

S162 (c) 2020 Springer Nature Limited. 1470-8914 Contemporary Political Theory Vol. 20, S4, S160-S163 
embed racial bias, discrimination, and inequality', and thus how 'racial data has become one vector of power through which racism maintains itself' (p. 113). Tracing the emergence of red-lining maps in the USA, Koopman convincingly shows how racial bias and discrimination were embedded from the start into the data themselves, and although at times he seems to resist this conclusion (p. 114), I take it to be one of the principal merits of his argument to clearly demonstrate that the 'politics of data' and the 'politics of race' inevitably tend to merge - another dangerous alliance that Koopman provides us with the conceptual tools to criticise.

Koopman's book is a rigorous, original, and timely contribution to contemporary political theory. Its relevance is even clearer today, in the midst of the covid-19 pandemic and the political unrest provoked by police brutality in the USA and beyond. The fact of the matter is that most of the ways in which we are currently governed would be simply inconceivable had we not already been constituted as informational persons, and had racism not been structurally embedded into this process from the very beginning.

\section{References}

de Beistegui, M. (2018) The Government of Desire: A Genealogy of the Liberal Subject. Chicago and London: The University of Chicago Press.

Foucault, M. (1984a) Nietzsche, genealogy, history [1971]. In: P. Rabinow (ed.) The Foucault Reader. New York: Pantheon Books, pp. 76-100.

Foucault, M. (1984b) What is enlightenment? [1984]. In P. Rabinow (ed.) The Foucault Reader. New York: Pantheon Books, pp. 32-50.

Harcourt, B. (2015) Exposed: Desire and Disobedience in the Digital Age. Cambridge, MA: Harvard University Press.

Publisher's Note Springer Nature remains neutral with regard to jurisdictional claims in published maps and institutional affiliations.

Daniele Lorenzini

University of Warwick, Coventry CV4 7AL, UK daniele.lorenzini@warwick.ac.uk

(C) 2020 Springer Nature Limited. 1470-8914 Contemporary Political Theory Vol. 20, S4, S160-S163 S163 